\title{
Chinese devils, the global market, and the declining power of Togo's Nana-Benzes
}

\author{
Nina Sylvanus
}

\begin{abstract}
This article examines the shifting representations of and discourses produced about Chinese salesmen and their collaborators in the small West African nation of Togo. It suggests that in this context representations of China's so-called New Scramble for Africa are troublesome, namely because they tend to silence the role of Togolese women traders as producers and as central historical and economic subjects in the making of a postcolonial commodity chain for printed African textiles. In so doing the article questions standard economic theories of global market forces, debunks stereotypes regarding the Chinese advance in West African markets, and challenges assumptions about the vulnerability of African societies.
\end{abstract}

\section{Introduction}

In April 2004, several variations of a rumor circulated throughout Lomé's GrandMarché, Togo's main market and a former hub for the distribution of import textiles in West Africa: a woman trader involved in the import of Chinese-produced fabric imitations had been murdered at her home. While the press, which eventually reported on the story, suggested that the circumstances of the murder remained unclear, the rumor had already circulated throughout the market. The victim had only recently set up her own business, and she had been relatively unknown to Lomé's well-established textile trading elite. According to the victim's servants, who had been locked in a closet by the four assailants, the victim was tortured and her legs were broken before she was killed. No jewels or money was stolen.

Because of their apparent lack of rationality, the two crucial elements of the storytorture before the killing and the absence of any theft-gave rise to speculations. Since such gruesome crimes were virtually unknown locally, the murder was instantly associated with the victim's trade partners: Chinese businessmen. As rumor had it, the victim had refused to deliver drugs she had smuggled into the country while importing cheap Chinese imitations of European-produced "African" fabrics from Shanghai. (The real European wax-print fabrics, which have been produced exclusively for the West African market since the late nineteenth century, hold a highrank status position in the long-standing local textile hierarchy and are among the 
most valued textiles in West Africa; see Sylvanus 2007). Another version claimed that she had attempted to negotiate a more profitable deal with a competing Chinese drug smuggling network. A third version added another element to the story: the trader had been bribing a key customs officer to facilitate her contraband activities. She recently had started missing payments, and the murder was a signal to the officer that he dare not reveal her illegal Sino-Togolese activities to the police. While only a few market women actually knew the victim, her sudden success in the trade of textiles had rendered many entrepreneurs suspicious about the real nature of her trade engagement.

The story offers a vivid snapshot of the tensions and shifting power relations that affect the market, topics that I wish to explore in this article by analyzing the recent shifts in the trade of globally produced "African" fabrics. As the rumors around the mysterious murder reveal, crime, conspiracy, corruption, and cupidity constitute the key components of the stories and rumors that define the relations among the different actors involved. Chinese businessmen appear as immoral, dangerous killers and drug smugglers, while the newly enriched trader in this story is represented as greedy, manipulative, and dishonest in her relations with both her business partner and the state, as symbolized by the customs officer with whom she collaborated. In this complicated morality tale, the illicit nature of their trade relationship with the Chinese appears central, part of the broader issue of illegitimate wealth production in which Chinese and Togolese traders appear as a conspiring entity-thus reflecting how morality intersects with new economic forms. Moreover, the fabric itself- the materiality of the Chinese copy-is considered suspicious because it destabilizes the role the European wax print (the superior original) had long performed in Togolese society. This article is thus concerned with these recent shifts to a new trade regime in which China holds central power.

\section{China in Africa/Togo}

The narratives of "fake" Chinese fabrics, tricksters, and traders offer a privileged lens through which to examine how Togolese interpret and assess current political transformations and changes in trade hierarchies. While rumors and scapegoating practices are intrinsic to economic transactions in general, the violent discourses revolving around the figure of the Chinese trickster (and his local associates) are interesting to explore with regard to their moral content. This is all the more true as the emerging subfield of China-Africa relations has focused on what is termed the "New Scramble for Africa," particularly on resource extraction, the politics of energy, trade, investment, and aid (see Alden et al. 2008; Large 2008; Taylor 2006). As Western governments, international organizations, and NGOs ponder the ways to "engage" China over Africa, as documented by cascading media reports, academic literature has focused on similar large-scale economic phenomena (see Broadman \& Isik 2006). Macrolevel analysis, however, tends to overlook the more intimate encounters-real or imagined-between "China" and "Africa." Numerous edited

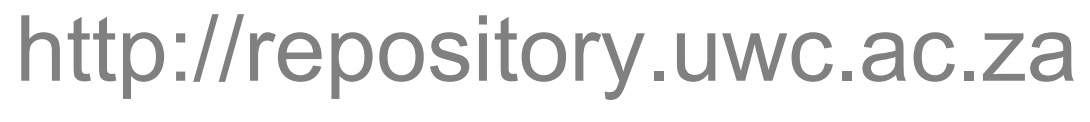


volumes and monographs tend to represent this trade as an invasion of a foreign economic structure into the passive body of Africa. From a postcolonial perspective, representations of "China's Africa Scramble" are troublesome, namely because they tend to silence local agency and overlook the dialectical process of collaboration and adaptation, which, in the case of the reorganization of the Togolese textile market, I found operative at many different levels. My intent here is not to offer an analysis of "resistance," as people are never just reacting. Rather, the article situates Togolese women traders (and, by extension, consumers) as producers and as central historical and economic subjects in the making of a postcolonial commodity chain for printed African textiles.

In The Dragon's Gift, Deborah Bräutigam captures an important aspect of the "China in Africa" trope by reminding us that the "Chinese are many things in Africa: touring presidents delivering grand promises for partnership, provincial companies with very long names[,]... factory managers demanding long hours of work, tough businesswomen, scrap metal buyers, traders" (2010:310). In this article, I examine how Togolese subjects have experienced, engaged, and interpreted the "many things" the Chinese were in Togo during a period of eight years (2002-10). By examining the shifting representations of Chinese agents (textile manufacturers, wholesalers, traders) and their operations, the article challenges stereotypical notions about the assumed cunning of the Chinese, the inevitability of their advance in West African markets, and the assumed vulnerability of African societies. In so doing, it also complicates standard economic theories of global market forces.

The data for this paper were drawn from ethnographic research and interviews conducted in Lomé between 2002 and 2004, in March-April 2008, and in December 2010. I conducted sixty interviews with women between the ages of eighteen and sixty-five working in the market as wholesalers, retailers, and employees. Most of these women came from families of traders and had mothers who had worked in the market as retailers or wholesalers of cloth or other commodities. I also conducted thirty interviews with consumers, mostly women but also men, who worked in government jobs, the private sector, or in Togo's booming informal economies. In addition, I conducted ten interviews with Chinese agents involved in the market in various capacities-as manufacturers, managers, and wholesalers-as well as their Togolese employees (drivers and interpreters). In the interviews participants discussed the life trajectories that had led them to their current positions, their family lives, and their aspirations for the future. In addition to conducting the interviews, I spent time with the participants in the marketplace and in their homes and was able to establish close personal relationships with several of them. ${ }^{1}$

The article begins with a brief historical overview of the Lomé market and its key actors, from its early postcolonial politics to more recent political transformations and their impact on the market. It then focuses on the reorganization of the market 
to discuss how long-held hierarchies and modalities of trade have shifted by exploring the trajectory of one trader, her travels to China, and her short-lived power monopoly in the Lomé market. A final section discusses how traders and consumers talk and think about "les Chinois" (and Chinese goods) and how one Chinese manufacturer views this relationship. I conclude by suggesting that notions of deviant "Chineseness" continue to be produced in Togo not simply as a reflection of the well-established presence of Chinese traders or goods, but rather as a way of talking about the neoliberal market, its new temporalities and modalities of competition. The Chinese devil, I argue, stands in for the global market itself and its double bind of inclusion and exclusion, which Togolese have experienced as a contradictory process: a development implying both possibility and impossibility, the fulfillment of aspirations and displacement.

\section{Market Politics}

Until the 1990s, Lomé's textile market was firmly controlled by a group of women traders, famously known throughout West Africa under the name "Nana-Benz." These traders had negotiated exclusive retail rights with colonial firms such as Unilever's United Africa Company and took on the regional distribution for European goods, including the trade in wax prints. These vibrant, multicolored patterned fabrics-a staple in women's clothing practices in large parts of West Africa-were introduced to West Africa at the end of the nineteenth century as a result of a broader imperial history that linked the sites of European industrial capitalism to Java and subsequently West Africa's Gold Coast. The origin of the wax print is linked to European, especially Dutch, attempts to mechanically reproduce Javanese batik cloth for the markets of the Dutch East Indies, and their subsequent relocation and reorientation to the West African market. By the end of the nineteenth century, Dutch and other European textile manufacturers had adapted the earlier approximations of Indonesian batiks to the taste and aesthetic preferences of West African consumers in an interactive process. Thus, a hybrid product at the outset, the Dutch wax print became a distinctly African consumable, despite its place of production. From the 1950 os onward, Togo's Nana-Benzes played a key role in the shaping of this market and in the making of the fabric as a West African consumable par excellence. 2

By the mid-1970s, the trade in textiles exceeded Togo's phosphate industry, which had long been the country's primary source of revenue. Meanwhile, the NanaBenzes consolidated their economic power through the creation of an oligopolistic market association that strengthened their trading interests and was a de facto representative of the dictator, Gnassingbé Eyadéma, himself. Eyadéma provided the Nana-Benzes with import licenses, low turnover taxes, and the region's lowest reexportation taxes during a period when most of Togo's neighbors faced political instability. In return, the Nana-Benzes expressed public support for Eyadéma and became involved in the women's wing of the ruling Rassemblement du Peuple Togolais (RPT). During the 1980s, however, the relationship between the political sphere and

\section{http://repository.uwc.ac.za}


Lomé's trading elite began to change. The authority of the Eyadéma regime was weakened with economic liberalizations, the withdrawal of imperial resources in the aftermath of the Cold War, as well as the liberalization of Togo's public sphere during a time of political liberalization and the embrace of la démocratie (see Piot 1999, 2010). In 1991-92 Eyadéma was temporarily expelled from power, and a number of second-generation textile traders sided with the opposition.3 During the time of the transitional government, members of Eyadéma's RPT vandalized and looted the traders' shops. In 1992, street protests and large-scale strikes in southern Togolese cities paralyzed the country's economy for almost eighteen months, and most of the textile traders, also fearing repression, left the country for Benin.

Eyadéma fraudulently returned to power in 1993, and two years of intense political tension followed. When Togo's trading elite, unable to prosper in Benin's protected economy, returned to Lomé in 1994, they found an economic environment that had changed profoundly, not only at the local level, but also at the regional and international levels. 4 Togo's Nana-Benzes found themselves in a profoundly restructured trade setting: Unilever's United Africa Company, the chief distributor of wax prints in West Africa, had sold its trading houses to the Dutch wax-print manufacturer Vlisco. When Vlisco took over Unilever's West African distribution units, it broke with Unilever's policies, including those arrangements the Nana-Benzes had negotiated during the late colonial period. With the demise of Togo's reputation of political and economic stability, and Cotonou's rise as a new trade hub for textiles, Lomé's trading elite thus entered a phase of reconfiguration that would permanently change the order of trade in Togo.5 The devaluation of the regional currency, the CFA franc, was another setback for Lomé's Nana-Benzes.

With the changes in the state apparatus, the regime not only retreated from its regulatory functions to take on a politics of survival, but it also retreated from its long-held role as patron over the economy. Eyadéma adopted a policy of economic laissez-faire and focused on his political succession rather than on governing. In 2003 he appointed one of his sons, Faure Gnassingbé, to a key ministerial position and made another son, Kpatcha Gnassingbé, the administrative head of the Lomé free port. In marketing the port and its neighboring free trade zone as a "flexible" host to the worlds' "global shadows" (Ferguson 2006), the regime made the entrepôt-port attractive to various "informal" networks, in particular Chinese traders.

When Eyadéma died in 2005, whatever political and economic regulations had persisted during his regime were essentially suspended. The controversial installment of the young Faure Gnassingbé by the military and his subsequent "official" election were marked by uncertainty. Power struggles and rivalries among 
Eyadéma's sons accentuated the diffusion of power, which has persisted despite Faure's reelection in 2010.

\section{Chinese Encounters}

The future of Togo, as conceived by the reelected president, will be a future marked by le changement (change) and a looking to the Far East instead of the West. The newly designed Web site of the Togolese Republic, which is part of a \$25million Chinese-financed "e-government" project to be implemented by the Chinese telecom giant Huawei, is particularly revealing. The entries there promoting Chinese corporations read like an announcement of the future-a future in which China will hold central importance. One announcement, for example, suggests that Chinese Great Wall cars, which recently were exhibited at Lomé's trade fair, will soon be replacing Peugeots and Renaults on the streets of Lomé.

But perhaps of the most immediate and obvious result of the Chinese influx has been felt among Togo's textile traders, formerly the backbone of the economy. The profitable trade in Dutch prints, once the monopoly of Togo's Nana-Benzes, has gradually lost its privileged economic status. Economic power is now in the hands of new women traders engaged in the import of cheap Chinese copies of the Dutch designs. A second-generation Nana-Benz, who had inherited her mother's trade empire in the 1980s, expressed her suspicions about the sudden wealth of these women.

These girls go to China only once or twice. They know nothing about textiles or the mechanism of the market, they don't come from trade families, nobody has ever seen them inside the Grand-Marché. And yet immediately after they return from Shanghai they construct fancy villas and purchase BMWs.... The money can't possibly come from the sales of Chinese textiles.

While her mistrust in the legality of the activities of her younger competitors indicates a mix of envy and anxious condemnation, it also indicates the shift taking place in the order of trade-from protected, monopolized markets to free markets. Her comment, which was echoed in the many stories and anecdotes I gathered in the market, reflected the elite's anxiety about its displacement by an emergent entrepreneurial nouveau riche that navigates the neoliberal market with savvy and enterprising flexibility. These younger women traders are referred to in the market as les Nanettes- contemporary, albeit smaller, versions of the "Nana-Benz." The murdered trader discussed in the opening section was just such a Nanette, standing in for a new order of trade in which moral standards are lax and greed, illicit trafficking, and collaboration with the state are the road to prosperity.

Anthropologists such as Comaroff and Comaroff (1993) have written about the ways in which figures of success and prosperity, along with culturally encoded associations between money and magic, indicate the contradictions brought on by 
"modernity and its malcontents." Togo's Nana-Benzes were long accused of being linked to the Mami Wata divinity- the water spirit that generates entrepreneurial success. But the success of the younger Nanettes is even more mysterious, and increasingly associated with new tricksters of the global market that have yet to be identified. While there have been no explicit witchcraft accusations against the Nanettes, speculation and rumors about the relationship between Chinese and newer traders are tinged with suspicion: Where does the money come from? How is it possible to accumulate such wealth in a decaying economy?

In 2003 I conducted a series of interviews with Antoinette Mensah, an entrepreneur famous for her role in the monopolization of the trade in damask fabric (see Sylvanus 2008). She was not a Nana-Benz (like many others, she had been unable to enter this highly controlled market), but she had become a prominent figure in the late 1970s when she controlled the import of damask (bazin) fabrics from Switzerland, Austria, and Germany. She also is part of the first generation of traders to explore Asian trade connections, and she was the first Togolese entrepreneur to visit mainland China (in early 2000). 6

African traders have been interested in trading with China since the 1970s, but Mensah's first experiences with the Chinese were in 1995. She had brought a set of samples, mostly non-wax prints, to Bangkok, and she wished to reproduce them as economically as possible. She met a Thai entrepreneur who introduced her to a colleague in Hong Kong who was the head of several textile manufacturing units. She worked with this Chinese manufacturer in Hong Kong for several weeks, and recalls his many misconceptions about African tastes. She had to point out repeatedly, for example, that her concern for her profit margin did not mean that she would accept goods that were shoddy or cheap.

The finishing of their fabrics was dumpy.... It was glossy and cheap looking. They didn't understand that Africans like the finishing being matte.... The fabrics were stiff and they had a taste of salt. I had to teach them everything and together we made samples over and over again until c'était bon. At the beginning they just couldn't understand that Africans really care for quality,...that quality is as important as the design of the fabric.

After weeks of "hard work," Mensah judged the results good enough for a trial run. She named the fabrics after her daughter, Sasa, and the "Super-Sasa" fabrics met with immediate success on the market, mostly because of their attractive price point in a postdevaluation period that had reduced the competitiveness of European products on African markets (see Bayart 2000:238).7 Mensah's business flourished as wholesalers throughout the region came to Lomé to purchase the fabrics; indeed, when she fully realized the potential of her Super-Sasa prints she repackaged the twelve-yard units she had sold for 12,000 francs CFA and turned 
them into six-yard units for the same price. 8 Her sudden success, however, had its negative side. The indications and symbols of her newly acquired wealth- her daughter's Mercedes, her new house, her well-situated shop and fancy delivery vangave rise to speculation, rumors, and criticism. She was said to be engaged in a conspiracy with her Chinese business partners and simply working as a figurehead for them. She was accused of cheating the population with this selling of "fake" fabrics. Then, in 1996, she was confronted with a more material challenge: a group of Togolese traders had her prints reproduced in India and copies of Super-Sasa fabrics entered the market. This was the beginning of an endless process of imitation and competition.

Despite this new twist, Antoinette Mensah remained in the game, refusing to be discouraged either by her local competitors or by the difficulties of dealing with the Chinese, who, as she put it, "really can't be trusted and...don't like Africans." Now, in fact, she represents a model of economic shrewdness to many of her colleagues from Lomé's Grand-Marché, who see the value of flexibility in one's trading ventures and admire the ability to switch from one market segment to another and adapt to ever-changing economic opportunities. Mensah herself became the first Togolese trader to explore China's Shandong region and soon established a partnership with a Shanghai-based company interested in reproducing European wax prints. In 2001 her new fabric, the "Mondial wax," arrived in Lomé, the first Chinese wax print to enter the market. It soon became a key product in Togo, Ghana, Benin, and Nigeria, where it was sold for a tenth of the price of the original Dutch Vlisco fabric and generated unprecedented profits. 9 Those in charge of distributing real Dutch Vlisco fabric, whom she had partially driven out of business, denounced her as a ruthless, cheating trader. But Mensah argues she has brought about a form of "consumption democratization" to Togo; "finally everybody can dress in wax: China wax is beautiful!”

Antoinette Mensah's exclusive control over the wax-print fabric was not permanent-she soon lost her monopoly when her Shanghai-based manufacturer expanded its customer network. While selling containers of the same product at different prices throughout the region, the Chinese manufacturer severely deregulated the local and regional market and engendered increased competition. Soon several competing Shanghai-based firms also entered the market, thus intensifying the deregulation. Mensah did not foresee this change, and this development was clearly out of her hands. Nevertheless, her colleagues in the market hold her partly responsible for having brought the free market to Togo, and she claims today that she wishes she had never started trading with these "Chinese devils." However, in contrast to common perceptions that attribute market transformation to the "invasion" of Chinese low-cost commodities, and to the collusion today of some of the so-called Nanettes, her story reveals a much more complicated trajectory-one that challenges the standard political-economy perspective that 
portrays women traders (when they are part of the analysis) as either being overrun by global structural forces and neoliberalism, colluding with those forces, or heroically resisting them. Her story, by contrast, provides a more nuanced representation of "China's Africa Scramble"-showing the inaccuracies in the usual dichotomous narrative and the ways in which the Africa-China relationship has been coproduced.

\section{Representations and Chinese Manufactures}

As elsewhere in West Africa, Togolese consumers have come to accept the presence of China and Chinese goods with a great deal of ambivalence- although, of course, such discourses have a long history in West Africa, particularly in situations of privation and change (see White 2000). I am not interested in the truth of stories such as the murder tale recounted above, but rather in what these narratives reveal about the way people have interpreted and experienced global changes and shifts in the market. For example, consider the symbolic interpretations regarding the fabric at the center of the story. The Chinese-made fabric, which had caused the trader's success and ultimate death, was a knock-off of the superior Dutch original. In the stories regarding the murder, the cloth itself was invested with deceitful and illicit meanings. By 2004 people were clearly aware of the origins of the fabric they were purchasing, but their comments about the trader still reflected lingering anxieties about being tricked out of their agency as consumers. "If I had a choice, I wouldn't buy these cheap copies that these Chinese devils produce," one of my informants had said in 2002. "If I had the money, I would never wear these nasty fabrics. I would buy Dutch, and only the authentic prints. The Chinese stuff, you wear it a couple of times, you wash it and there's nothing left, you have to replace it." This woman was a notary by profession and she explained that her financial situation obliged her to buy Chinese knock-offs: her children were studying in Canada and the U.S. and she cannot afford Vlisco fabrics. But her peers would consider her as no longer being "up to date" if she continued to wear the same Vlisco outfit to all social events.

I repeatedly came across the perception that the Chinese, contrary to the claims of the Togolese state, did not come to Africa for the sake of mutual development, attracted by the absence of conditionalities to Beijing's assistance, but rather to advance themselves and confine Africans in poverty. While several Togolese I spoke to in the early 2000 s viewed China's involvement as a positive development ("at least they haven't abandoned us like the West," stated a bank employee), many expressed concern about the real nature of their engagement. "They don't work with us, they bring in their Chinese prisoners to do the construction," said a zemidjan (moto-taxi) driver in 2002. "They're building the new presidential palace so that they have a free hand," explained a soft-drink vendor in the market. In the summer of 2004 a fabric trader in the market explained with annoyance, "Chinese only imitate, they don't develop products for us, they don't care, they just want their factories to continue producing, they can't consume all these products, so we are getting their junk." Another trader, similarly infuriated, said "they don't adapt to us, they 
do all their business in Chinese.... They speak no French or English ... and they don't like to mix with locals, they only keep to themselves.... They don't even give you receipts and you have to pay in cash!" Still others, as echoed in the murder story, suspect that drug smuggling is part of the Chinese operations. Such accounts present Chinese traders and business modalities as defined primarily by "lack": a lack of accountability, a lack of morality and transparency, and more generally, a lack of humanity. ${ }^{10}$

I repeatedly encountered views regarding the perceived "otherness" and inhumanness of les Chinois. While most people I spoke to between 2002 and 2004 had indeed consumed Chinese goods, few of my interviewees (with the exception of the wholesale traders in the market) had in fact interacted with les Chinois on a face-to-face basis; instead, many accounts of spectacular Chinese "otherness" appeared to rely on rumors and stories retold by friends of friends. Such stories ranged from Chinese culinary practices-they were said to preserve snakes and monkeys in jars, which Togolese considered to be a sign of their "savageness"-to vicious trade practices: "They show you fabric samples, they give you a price, and then they go next door and they sell the same sample at a lower price. They make a mess and destroy our business."11

In 2010, stereotypical representations of "Chinese-ness" continued to circulate in Togo, and caricatures of le Chinois-not unlike West African jokes of the colonial period about le Blanc or le Colon, the white colonizer- appeared in popular jokes and cartoons, reflecting the established presence of a Chinese community in the popular culture. The increased visibility of China on the streets of Lomé (from karaoke bars, restaurants, fast-food street-vending operations, and massage studios to Chinese construction workers and supervisors) and the everyday encounters with "China" (be it via traders, shop owners, goods, or media representations) signaled a shift in perception. Togolese realized that the Chinese presence was not a transitory phenomenon-that the Chinese had come to stay and inevitably were part of their futures, as reflected in the state's active courting of China. Most Togolese had indeed became active consumers of Chinese goods, knock-offs of old-world commodities, and although many had stories to tell about the poor quality-of Chinese matches breaking, of low-performing cell-phone batteries, of skin-irritating soaps and flawed air conditioners - other observers acknowledged some value. As one of my interviewees amusingly stated in reference to the increasingly segmented market of Chinese goods available in Lomé, "there are different degrees of Chinois."

An illustrative case is provided by the Chinese textile manufacturing firm of Auden. As a regional manager of the company explained, by 2008 several Chinese textile manufacturers had changed their production and marketing strategies. While during the early 2000s Chinese manufacturers were eager to establish local networks to expand their clientele, they eventually limited these networks. While Auden had a rocky

\section{http://repository.uwc.ac.za}


start, initially struggling to finding what my interlocutor called "reliable clients," he explained that "we don't want any more clients, we have too many clients already,... our factories can hardly keep up with the ever-increasing demand." This development contrasted with contentions about China's presumably insatiable hunger to expand its market share, or with newspaper headlines of Chinese textile dumping.

At the same time, Auden's place in the Togolese market was by no means secure or guaranteed. The strategic shift in Chinese wax cloth manufacturing has involved not only changes in distribution but also in the segmentation of the waxprint market. Today, several Chinese factories produce and compete in the superior quality market, and although this product is inferior to the Dutch "original," it has come to occupy a real market niche. As elsewhere in West Africa, Togolese consumers increasingly

value this high-end segment, and several Chinese labels-especially Hitarget or Phoenix-have become desirable commodities for which consumers are willing to pay up to 13,000 francs CFA (compared to 45,000 for the original Vlisco). These new labels attract consumers who previously bought the Nigerian-produced Nichemtex or the Ghanian-produced ATL (both owned by the Hong Kong-based group Cha Chi Ming) as well as the Ivorian- and Ghanaian-produced labels Uniwax and GTP (which are owned by Vlisco). 12 In 2008, when discussing intra-Chinese competition with another interlocutor from the Auden firm, I learned of the firm's fear of industrial espionage-a concern that was a strange reminder of the practices of the European textile manufacturers who began producing prints for the West African market during the early twentieth century. Competition was fierce, and one manager even received instructions from Shanghai not to mix with other Chinese. In the case of Auden, such measures appear to have been in vain. In December 2010 I drove to its former Togolese office- a large villa located in a residential neighborhood not far from the Lomé free port where the Chinese employees also lived-only to find that the company had abandoned its operation. Moreover, while Auden wax prints had known considerable success during my previous visits, the fabrics had virtually disappeared from the market. A wholesale trader explained that the firm's quality had declined so significantly that she chose to sell other Chinese labels, namely Hitarget. The example of a manufacturer such as Auden, whose products were initially successful but were subsequently abandoned, is significant to note, and stories such as this one tend to be overlooked in the literature on "China's Africa Scramble." At least in the context of Chinese manufacturing of African prints, it is safe to suggest that intra-Chinese competition constitutes an important node of the story.

\section{Conclusion}

In 2004, few Lomeans had actually encountered Chinese traders, but Lomé's rumor mill was flush with stories about them and those who collaborated with them. Representations of "the Chinese" were relatively vague and often rather spectacular,

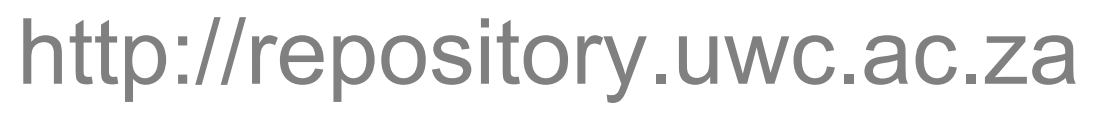


not only in the rumors about the real story behind the murder but also, for example, in stories such the one about monkeys allegedly being preserved in jars. But these stories nevertheless indicated that les Chinois had come to occupy a place in local cosmologies. By 2006, only two years following the circulation of the vicious rumor, China's presence in Lomé had become real and visible to most of the city's inhabitants, in ways that included, in fact, Togo's first anti-Chinese protest march in the market. 13

As elsewhere in Africa, not only did Togolese consumers encounter Chinese retailers in the market, but more significantly, Chinese goods had become a staple to nearly all. What initially may have been perceived as a possibility-Togo's dependence on China as chief provider of consumer goods and, by extension, Togo's disconnection from the Global North-rapidly became an economic reality. In 2010 a cartoon that appeared in the popular Lomé magazine Sika'a particularly amused some of my trading friends in the market. 14 The sketch showcased an encounter between a woman trader, sitting in front of a market stall, and a Chinese salesman carrying an overflowing suitcase of Yuan bills leaving his own stall selling "development from below" (dévélopment à la base). The woman interpellates the Chinese with a colloquial, "Chinois, j'ai du bon manioc, il faut acheter" (Chinese, I have good cassava, you must buy), while the Chinois responds "Ah oui, oh yes, it must surely be very good" (my translation). What made my friends in the market laugh was not merely the fact that the man's response included several mispronunciations of the French (in stereotypical fashion the cartoonist had replaced the letter " $s$ " with the letter "l" in several words, which made for a stutteringlike effect), 15 but rather the fact that le Chinois in fact had no real power. When I asked them to specify, they explained that the Chinese, after all, are not "as savvy as people say they are." My interlocutors, two Nanettes who themselves had traveled to China many times and who imported large quantities of Hitarget fabrics, insisted that what the sketch captured so accurately was the fact that the Chinese "really are not their own agents" but are "simply executors" of another's project: that is, of Chinese capitalism itself, as symbolized in the overflowing suitcase of currency carried by an agent who not only does not master the language, but who also has no clue about cassava or other local specificities. By unveiling and mocking the weakness of the Chinese in the Lomé market, the cartoon (and the Nanettes' comments) were pointing to a dimension to the China-in-Africa story that often is overlooked in the literature-that is, China's relative vulnerability in West African markets. Of course, as one of my informants said, "there are different degrees of Chinois," and the Chinese, as we have seen are never just "one thing," in Togo as in other parts of Africa. And that is the point. If the cartoon mocks Chinese incompetence, the Lomé market case, as this article argues, puts into perspective the myth of a Chinese assault on West African markets and, by extension, the assumed vulnerability of African societies. 


\section{Acknowledgments}

Versions of this paper were presented at the 2007 UCLA Globalization Research Center Africa workshop "Rethinking Africa's 'China Factor': Identifying Players, Strategies, and Practices." I wish to thank Ed Keller for his confidence and generous support in helping me put together this event. An expanded version of the UCLA paper called "Death in the Market: Rumors of the Chinese Devil in Togo" was presented during the AAA Meetings in Washington, D.C., in November 2007, where Misty Bastian not only provided sharp and thought-provoking commentary but also invaluable post-food poisoning support. I am also grateful for the insightful comments of the anonymous reviewers of ASR. Finally,

I wish to thank the Center for the Humanities (CHR) at the University of the Western Cape (UWC) and the Mellon Foundation for a generous fellowship that allowed me to work on the revisions of this paper, and a book manuscript provisionally entitled "Print Value: The Dressed Body and Its Economies in WestAfrica." 


\section{References}

Alden, Chris, Daniel Large, and Ricardo Soares de Oliveira. 2008. China Returns to Africa.London: Hurst.

Bayart, Jean-Francois. 2000. "Africa in the World: A History of Extraversion." African Affairs 99: 21767.

Bräutigam, Deborah. 2010. The Dragon's Gift. Oxford: Oxford University Press. Broadman Harry G., and Gozde Isik. 2006. Africa's Silk Road: China and India's New Economic Frontier. Washington, D.C.: World Bank Publications.

Cooper, Frederik. 2002. Africa since 1994: The Past of the Present. Cambridge: Cambridge University Press.

Comaroff, Jean, and John Comaroff. 1999. "Occult Economies and the Violence of Abstraction." American Ethnologist 26 (2): 279-303.

---. 1993. Modernity and Its Malcontents: Ritual and Power In Postcolonial Africa. Chicago: University of Chicago Press.

Ellis, Stephen. 1993. "Rumour and Power in Togo." Africa: Journal of the International African Institute 63(4): 462-76.

Ferguson, James. 2006. Global Shadows: Africa in the Neoliberal Order. Durham, N.C.: Duke University Press.

Heilbrunn, J. R. 1993. "Social Origins of National Conferences in Benin and Togo." Journal of Modern African Studies 31 (2): 277-99.

Large, Daniel. 2008. "Beyond 'Dragon in the Bush': The Study of China-Africa Relations." African Affairs 107(426):45-61.

Macé, Alain. 2004. "Politique et démocratie au Togo 1993-1998: de l'espoir à la désillusion." Cahiers d'Etudes Africaines 44(4):841-85.

Nwajiaku, Kathryn. 1994. “The National Conferences in Benin and Togo Revisited." Journal of Modern African Studies 32 (3): 429-47.

Piot, Charles. 1999. Remotely Global: Village Modernity in West Africa. Chicago: University of Chicago Press.

---. 2010. Nostalgia for the Future: West Africa after the Cold War. Chicago: University of Chicago Press.

Sylvanus, Nina. 2007. "The Fabric of Africanity: Tracing the Global Threads of Authenticity." Anthropological Theory 7 (2): 201-16.

---. 2008. "Rethinking Free-Trade Practices in Contemporary Togo: Women Entrepreneurs in the Global Textile Trade." In Globalization and Transformations of Local Socio-economic Practices, edited by U. Schuerkens, 174-191. London: Routledge.

---. 2009. "Commercantes togolaises et diables chinois: Une approche par la rumeur." Politique Africaine 113: 55-70.

Taylor, Ian. 2006. China and Africa: Engagement and Compromise. New York: Routledge.

White, Luise. 2000. Speaking with Vampires: Rumor and History in Colonial Africa. Berkeley: University of California Press. 


\section{Notes}

1. Reconstructions of events and quotations are all based on the collected data. To protect my interviewees' privacy, I have chosen to conceal their identities. The opening anecdote and some of the ethnographic evidence appeared previously in an article published in Politique Africaine (Sylvanus 2009). Thanks to the editors of Politique Africaine for permission to reprint this material.

2. Wax prints soon became associated with sartorial elegance which affluent consumers used as a signifier of elite status to mark social hierarchy in a rapidly changing society.

3. See Heilbrunn (1993); Kwajaku (1994); Ellis (1994); Mace (2004). A few elderly women traders remained neutral during this period, but most market women played central roles in the newly founded political parties.

4. Eyadéma incited the economic elite to return to Togo notably by playing the card of xenophobia in a series of broadcasts that mobilized the figure of the foreign trader as taking over the economy.

5. Benin not only became a model of successful democratic transition, but the port city also benefitted from the Togolese crisis and took over its regional trade during this period of political and economic transition.

6. The following account of her activities is based on interviews and conversations with her as well as one of her employees.

7. "Sasa" and "Super-Sasa" are not the real names.

8. 1,000 francs CFA is equal to approximately US $\$ 2.00$

9. Vlisco copies, notably from India and Pakistan, had existed in the market before, but Mondial wax was the first copy using the actual Dutch technique.

10. It is ironic to note here that the language of "lack" is usually employed to describe the disorder and inefficiency of postcolonial African cities in development discourse (see Ferguson 2006).

11. This was spoken by a young wholesale trader who had inherited her mother's business and today struggles to diversify her business. But adding Chinese fabrics to her repertoire has largely proved to be a failure.

12. In the case of Cha Chi Ming (or CHA), it is useful to note that the group has operated in West Africa since the 1960s. What is equally worth noting is that the Auden manager I spoke to had built his entire career in Ghana as a textile engineer with CHA until he was hired away by the Shanghai-based Auden in 2004. West African postindependence textile markets had indeed attracted a number of "Asian" investors. As postcolonial African states established national textile industries as the backbone of their economies - thus promoting "authentic" African dress styles and prints-the Hong Kong industrialist, textile engineer, and entrepreneur Cha Chi Ming extended his textile enterprise to West Africa (Nigeria) in 1964. During the 1960 s and 1970s CHA deployed several hundred Hong Kong Chinese workers, textile engineers, and designers to Nigeria and Ghana. To this day CHA owns several factories and brands, which are distributed throughout West Africa. In the 1990s, the group CHA bought the historic Manchester textile mill ABC (Vlisco's historic competitor) where wax prints had been produced for West African markets since 
1908. In 2008 production ceased in Manchester and ABC machinery was transferred to Ghana, where CHA continues to produce its brands ATL and ABC.

13. In December 2006 an anti-Chinese demonstration was organized by a group of women traders. Unlike wholesalers, who travel to China and place their orders directly at the site of production, small-scale traders had become dependent on a series of new intermediaries, not only Chinese, but also Sahelien, Indian, and even Iranian agents. Several cases of agents delivering unsatisfactory merchandise-or, in rare cases, of disappearing with the trader's money altogether-as well as cases of Chinese retailers selling at prices no Togolese small-scale trader could compete with, resulted in the women's protest march. Giving visible expression to what local traders perceived as discriminatory trading, the movement called for political regulation of the problem. A legal decree in support of their position has essentially been unenforced in practice.

14. Sika'a magazine's biweekly edition of 7,000 circulates widely throughout the Togolese capital at the moderate cost of 250 francs CFA. The caricature described here appeared in Sika'a 80 (December 14, 2010).

15. "Ca doit etle sulement eles bon" reads the Sika'a caricature, instead of "ça doit être sûrement très bon." 